as in previous studies, ${ }^{78}$ we compared peak expiratory flow rates over seven day periods during respiratory episodes and control periods. By doing this we may have failed to recognise brief asthma exacerbations with modest decreases in peak expiratory flow rate, but we were less likely to include as exacerbations variability in airflow related to poorly controlled asthma.

None of the previous studies in adults tested for coronaviruses, and Huhti et al did not culture for rhinoviruses. ${ }^{6}$ In our study, identifications of rhinoviruses by seminested reverse transcriptase polymerase chain reaction and coronaviruses by ELISA improved the diagnosis of both viruses and enabled us to show that they are important causes of respiratory disease leading to exacerbations of asthma in adults as well as in children. ${ }^{242425}$ Given the far better performance of polymerase chain reaction than conventional diagnostic techniques, the newer molecular methods should greatly facilitate research in this important area.

This work was in part supported by the British Lung Foundation and the Cystic Fibrosis Trust. We thank Mrs L Jacklin for excellent technical assistance; Drs J Wales, J B Cookson, M Morgan, M Stern, J Jolleys, M Shanks, G Prowse, G Cook, $\mathrm{K}$ Baker, and J H Turner for access to their patients; Mrs M Emmerson for help in following up volunteers; Dr M Stern for helpful comments and support; and especially the volunteers, without whom this work would not have been possible.

1 Minor TE, Baker JW, Dick EC, DeMeo AN, Ouellette JJ, Cohen M, et al.

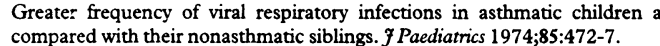

2 Minor TE, Dick EC, Baker JW, Ouellette JJ, Cohen M, Reed CE. Rhinovirus and influenza type A infections as precipitants of asthma. Am Rev Resp Dis
and and influenza type

3 McIntosh K, Ellis EF, Hoffman LS, Lybass TG, Eller J, Fulginiti VA. The association of viral and bacterial respiratory infections with exacerbations of wheezing in young asthmatic children. Pediatrics 1973;82:578-90.

4 Minor TE, Dick EC, DeMeo AN, Ouellette J, Cohen M, Reed CE. Viruses as precipitants of asthmatic attacks in children. $¥ A M A$ 1974;227:292-8.

\section{Use of chaperones by general practitioners}

\section{Arie Speelman, James Savage, Mariike Verburgh}

The Surgery, Staithe Road, Ludham, Norfolk NR29 5AB

Arie Speelman, trainee general practitioner

James Savage, general practitioner Marijke Verburgh, trainee general practitioner

Correspondence to: Dr Speelman.

$B M \Im$ 1993;307:986-7
5 Horn MEC, Reed SE, Taylor P. Role of viruses and bacteria in acute wheezy bronchitis in childhood: a study of sputum. Arch Dis Child 1979;54:587-92.

6 Huhti E, Mokka T, Nikoskelainen J, Halonen P. Association of viral and mycoplasma infections with exacerbations of asthma. Ann Allergy 1974;33: $145-9$.

7 Hudgel DW, Langston L, Selner JC, McIntosh K. Viral and bacterial infections in adults with chronic asthma. Am Rev Resp Dis 1979;120:393-7.

8 Beasley R, Coleman ED, Hermon Y, Holst PE, O'Donnell TVO, Tobias M. Viral respiratory tract infection and exacerbations of asthma in adult patients. Thorax 1988;43:679-83.

9 Nicholson KG, Baker DJ, Farquhar A, Hurd D, Kent J, Smith SH. Acute upper respiratory tract viral illness and influenza immunization in homes for the elderly. Epidemiol Infect 1990;105:609-18.

10 Wiselka MJ, Nicholson KG, Kent J, Cookson JB, Tyrrell DAJ. Prophylactic intranasal alpha-2 interferon and viral exacerbations of chronic respiratory disease. Thorax 1991;46:706-11.

11 Ireland DC, Kent J, Nicholson KG. Improved detection of rhinovirus in nasal and throat swabs by semi-nested RT-PCR. 7 Med Virol 1993;40:96-101.

12 American Thoracic Society. Definitions and classification of chronic bronchitis, asthma, and pulmonary emphysema. Am Rev Resp Dis 1962;85:762-8.

13 Beare AS, Reed SE. The study of antiviral compounds in volunteers. In: Oxford JS, ed. Chemoprophylaxis and virus infections of the respiratory tract. Vol 11. Cleveland: CRC Press, 1977:27-76.

14 Kraaijeveld CA, Reed SE, Macnaughton MR. Enzyme-linked immunosorbent assay for detection of antibody in volunteers experimentally infected with human coronavirus 229E. 7 Clin Microbiol 1980;12:493-7.

15 Don RH, Cox PT, Wainwright BJ, Baker K, Mattick JS. "Touchdown" PCR to circumvent spurious priming during gene amplification. Nucleic Acids Research 1991;19:4008.

16 Lo Y-MD, Mehal WZ, Fleming KA. False-positive results and the polymerase chain reaction. Lancet 1988;ii:679.

17 Wiselka MJ, Kent J, Nicholson KG, Stern M. Influenza and asthma. Lancet 1992;339:367-8.

18 Johanson WVG, Pierce AK, Sanford JP. Pulmonary function in uncomplicated influenza. Am Rev Resp Dis 1969;100:141-6.

19 Picken J, Niewohner DE, Chester EM. Prolonged effects of viral infections of the upper respiratory tract upon small airways. $A m$ f Med 1972;52:738-46.

20 Horner GJ, Gray FD. Effect of uncomplicated, presumptive influenza on the diffusing capacity of the lung. Am Rev Resp Dis 1973;108:150-5.

21 Fridy WW, Ingram RH, Hierholzer JC, Coleman MT. Airway function during mild viral respiratory illness. Ann Intern Med 1974;80:150-5.

22 Blair HT, Greenberg SB, Stevens PM, Bilunos PA, Couch RB. Effects of rhinovirus infection on pulmonary function of healthy human volunteers. Am Rev Resp Dis 1976;114:95-102.

23 Hall WJ, Hall CB. Respiratory syncytial virus infection in adults: clinical, virologic, and serial pulmonary function studies. Ann Intern Med 1978;88: 203-5.

24 Mertsola J, Ziegler T, Ruuskanen O, Vanto T, Koivikko A, Halonen P. Recurrent wheezy bronchitis and viral respiratory infections. Arch Dis Child 1991;66:124-9.

25 Lambert HP, Stern $\mathrm{H}$. Infective factors in exacerbations of bronchitis and asthma. $B M Y 1972$;iii:323-7.

(Accepted 17 August 1993)

without a chaperone. Their comments generally suggested that they had never thought it necessary to have a chaperone present; some said that it had never crossed their minds.

In all, 181 questionnaires were returned by the male doctors, the mean age of whom was $42 \cdot 8$ years. Ninety eight worked in rural practices. Only two doctors did not have a practice nurse available. Many used a chaperone with young patients. Other reasons for use included fear of litigation (41), the doctor's knowledge of the patient (13), and intuition (22). The main reasons given for not using a chaperone were too time consuming, impractical, unnecessary, and not beneficial to the doctor-patient relationship. Sixty six thought that the use of a chaperone could damage the doctor-patient relationship, while 80 thought the opposite. Thirty one male doctors felt uncomfortable and 129 felt comfortable without a chaperone. We found no correlation between the frequency of use of chaperones and the practice size or doctor's age.

Male doctors mostly used practice nurses (135) as chaperones, but some also used receptionists (40), dispensers (one), and practice managers (two).

A questionnaire was sent to 200 randomly selected male and to all 60 female general practitioners listed by Norfolk Family Health Services Authority. It asked about doctors' characteristics and their use of chaperones when examining patients of the opposite sex-for example, to take a cervical smear or assess testicular swelling. The results were analysed by computer with the Epi Infor version 5 statistical program separately according to the doctor's sex and are shown in the table.

Fifty one questionnaires were returned by the female doctors. Forty seven felt comfortable examining

Use of chaperones by general practitioners according to sex of doctor. Values are numbers (percentages) of doctors

Never Rarely Sometimes Always

\begin{tabular}{lrrrr}
\hline Female $(\mathrm{n}=51):$ & & & & \\
Intend to use chaperone & $38(75)$ & $10(20)$ & $3(6)$ & 0 \\
Intend to offer chaperone & $40(78)$ & $8(16)$ & $3(6)$ & 0 \\
Male $(\mathrm{n}=181):$ & & & & \\
Intend to use chaperone & $38(21)$ & $79(44)$ & $35(19)$ & $29(16)$ \\
Intend to offer chaperone & $62(34)$ & $57(32)$ & $34(19)$ & $24(13)$ \\
\end{tabular}




\section{Comment}

Our results show that female general practitioners never or rarely used a chaperone and felt comfortable examining a male patient without one. However, the defence organisations strongly advise both female and male doctors always to use a chaperone. Few female general practitioners pointed out the logistic difficulties in obtaining a suitable chaperone for a male patient; others prefer to refer the patient for examination to a male partner when necessary.

About $65 \%$ of male general practitioners never or rarely used a chaperone, or even intended to offer a chaperone. However, $16 \%$ always used a chaperone. These results are similar to those of Jones in $1983 .{ }^{1}$ It seems inappropriate that up to $25 \%$ of male general practitioners use medically unqualified staff such as receptionists as chaperones.
In conclusion, a chaperone seems justified in selected cases, for young patients, and for medicolegal reasons; however, the availability of a full time chaperone would have financial implications and may damage the doctorpatient relationship. There seems to be a disparity between doctors' views and medical defence organisations' advice. General practitioners should be able to offer their patients a suitably qualified chaperone, and the decision to use one should be a two way interaction between the doctor and the patient.

We thank all staff and doctors in our practice, the staff of Norfolk Family Health Services Authority, and all doctors who returned the questionnaires.

1 Jones RH. The use of chaperones by general practitioners. $f R$ Coll Gen Pract 1983;33:25-6.

(Accepted 25 fune 1993)

\section{Condoms: a wider range needed}

\section{Stuart J Tovey, Christopher P Bonell}

Lloyd Clinic, Department of Genitourinary Medicine, Guy's Hospital, London SE1 9RT

Stuart John Tovey, consultant physician in charge

Clinical Audit Team, Guy's Hospital, London SE1 9RT Christopher P Bonell, clinical audit officer

Correspondence to: Dr Tovey.

$B M \mathcal{F}$ 1993;307:987 condoms coming off as well as splitting.
Previous research has assumed that condom failures, other than those due to manufacturing faults, have been the result of user behaviour or condoms being too loose. We report the findings of a survey of men attending a busy genitourinary medicine clinic in an area of south London with one of the highest incidences in Britain of pregnant women positive for HIV. The results of our study indicate that tightness of condoms is an important factor in their failure and suggest that a larger condom may be needed by some individuals and that this would reduce the risk of

\section{Methods and results}

Three hundred men attending the clinic were asked to answer a questionnaire; 281 were returned. In their responses 188 men considered themselves white, 76 black, and 14 Asian.

Seventy men ( $25 \%$ of the sample) reported difficulties putting on condoms, of whom $52(19 \%$ of the sample) said that condoms were too tight. Seventy three per cent (38) of these men had experienced condoms coming off, compared with $52 \%$ respondents (96) who reported that they were not too tight. Of respondents who said condoms were too tight, $68 \%$ (34) reported splitting, compared with $52 \%$ (95) of those who reported that they were not too tight. Condoms coming off occasionally had been experienced by $22 \%$ (17) black, $27 \%$ (51) white, and $36 \%$ (5) Asian men, and $8 \%$ (6) black, $2 \%$ (3) white, and $21 \%$ (3) Asian men had had condoms come off frequently. In all, $20 \%$ (15) black, $19 \%$ (35) white, and $28 \%$ (4) Asian men had occasionally had a condom split, and $18 \%$ (14) black, $7 \%$ (14) white, and no Asian men had experienced condoms splitting frequently.

Sex with two or more partners during the preceding 12 months was reported by $56 \%$ (157) of respondents (53\% (99) white, $70 \%$ (53) black, and 36\% (5) Asian). Although $22 \%$ of the sample (63 men) claimed to always use a condom, only $9 \%$ (7) of black men, compared with $27 \%$ (51) of white and $36 \%$ (5) of Asian men, made this claim.

\section{Comment}

Most condoms in Britain conform to the specifications of the British Standards Institute, which specify a flat width of 52 (SD 2) $\mathrm{mm} .{ }^{1}$ Our results suggest that a
Relation between condom tightness, condom failure, and racial origin. Values are numbers (percentages); not all subjects answered all questions

\begin{tabular}{lccc}
\hline & $\begin{array}{c}\text { Condom tight } \\
(\mathrm{n}=52)\end{array}$ & $\begin{array}{c}\text { Condom not tight } \\
(\mathrm{n}=186)\end{array}$ & $\mathrm{p}$ Value \\
\hline Condom came off $(\mathrm{n}=250):$ & & & 0.0003 \\
$\quad$ Frequently & $6(12)$ & $4(2)$ & \\
Occasionally & $32(64)$ & $92(49)$ & \\
$\quad$ Never & $12(24)$ & $90(48)$ & 0.0001 \\
Condom split $(\mathrm{n}=249):$ & $13(26)$ & $14(11)$ & \\
$\quad$ Frequently & $21(42)$ & $18(15)$ & \\
Occasionally & $16(32)$ & $92(74)$ & 0.0007 \\
Never & $25(48)$ & $40(22)$ & \\
Racial origin $(\mathrm{n}=281):$ & $25(48)$ & $136(73)$ & \\
$\quad$ Black & $2(4)$ & $10(5)$ & \\
White & & & \\
Asian & & & \\
\end{tabular}

${ }^{\star} \chi^{2}$ Test with two degrees of freedom.

proportion of men have penises sufficiently large to cause difficulty in putting on condoms, and for these men condoms are likely to come off or split more often, which may influence the acceptability of condoms. It is often assumed that a condom is elastic and that, size is therefore unimportant, but little stretch is actually possible when the condom is in a tightly rolled state.

An important cause of a condom coming off, paradoxically, is that it may be too tight. Difficulty rolling the condom fully down the shaft allows the ring to enter the partner and be rolled off the penis. If a condom is tight breakage may be due to placing fingers inside the ring to drag on the condom; this accounts for breakage occurring most often at the closed end (S L Solanti, personal communication).

Failure related to tightness would contribute to negative images of condoms. The World Health Organisation's guidelines indicate that over a third of penises exceed the British Standard Institute's standard dimensions for condoms. ${ }^{2}$ This standard therefore inhibits the manufacture of a suitable range of size of condoms. This aspect of condom design needs further research.

The survey also highlighted a higher reported rate of condom failures, lower uptake of condoms, and reporting of a greater number of partners by black respondents. These findings indicate that this group, who may be at particular risk of exposure to HIV infection through second generation spread, could benefit from specific promotion and products.

We thank Dr J Rees, Mr D Cobell, and Mr W Motaleb for their invaluable help.

1 British Standards Institute. British Standard specification for natural rubber latex condoms: $B S 3704$.

2 World Health Organisation. Specifications and guidelines for condom procurement. Geneva: WHO, 1992.

(Accepted 13 Fuly 1993) 